\title{
Pemberian Edukasi tentang Peran Orang Tua dalam Pencegahan COVID-19 pada Anak Pra Sekolah
}

\author{
Nidatul Khofiyah $^{1^{*}}$, Fitnaningsih Endang Cahyani ${ }^{2}$ \\ ${ }^{1,2}$ Universitas 'Aisyiyah Yogyakarta, Jl. Siliwangi Jl. Ringroad Barat No.63, Area Sawah, \\ Nogotirto, Kec. Gamping, Kabupaten Sleman, Daerah Istimewa Yogyakarta 55592 \\ E-mail: idatulkhofiyah@unisayogya.ac.id ${ }^{1 *}$
}

\begin{abstract}
ABSTRAK
Berkembangnya virus corona saat ini tidak hanya berdampak di bidang kesehatan namun juga pada sektor lainnya termasuk pendidikan. Pemerintah mengeluarkan peraturan bahwa proses pendidikan dan pembelajaran dilakukan dirumah dengan pendampingan langsung oleh orang tua. Akibat dari COVID-19 ini juga dapat menyebabkan kecemasan pada berbagai pihak tidak terkecuali para orang tua. Dengan banyaknya pemberitaan mengenai COVID-19 di televisi bahkan media sosial membuat orang tua merasa cemas dan dapat menularkan kecemasan tersebut kepada anak-anak. Dampak dari COVID-19 ini dirasakan oleh semua pihak tidak terkecuali para orang tua wali siswa di Kelompok Bermain/RA Alfa Kids Purworejo. Banyak orang tua yang merasa cemas dan panik dengan adanya COVID-19 ini. Selain cemas karena takut penularan terhadap anak tetapi juga karena pandemi ini memaksa beberapa pekerjaan orang tua menjadi terkendala sehingga membuat kesulitan secara ekonomi. Oleh karena itu, pemberian edukasi pada orangtua diperlukan untuk meningkatkan pengetahuan dan mengurangi kecemasan orangtua terhadap kondisi pandemi. Metode yang digunakan Luaran yang dihasilkan adalah (1) Tersusunnya video dan booklet sebagai media informasi, (2) edukasi kepada orang tua terlaksana dengan baik via daring, (3) pemberian bantuan untuk orang tua dan guru yang terdampak pandemi COVID-19 ini terdistribusi sesuai yang membutuhkan (4) publikasi. Berdasarkan hal tersebut diharapkan pelaksanaan kegiatan pendidikan anak dirumah dapat berjalan dengan baik, anak-anak dapat menerapkan protokol kesehatan sesuai yang diharapkan.
\end{abstract}

Kata Kunci: Pandemi COVID-19; Pendidikan; Edukasi; Kecemasan

\begin{abstract}
The development of the current corona virus has an impact not only in the health sector but also in other sectors including education. The government issued a regulation that the education and learning process is carried out at home with direct assistance by parents. The consequences of COVID-19 can also cause anxiety to various parties, including parents. With so much news about COVID-19 on television and even social media, it makes parents feel anxious and can transmit this anxiety to children. The impact of COVID19 is felt by all parties, including the parents of students in the Play Group/Kindergarden Alfa Kids Purworejo. Many parents feel anxious and panic about COVID-19. Apart from being anxious because they are afraid of transmission to children, but also because of this pandemic, they are forcing some of the work of parents to be constrained, thus creating economic difficulties. Therefore, providing education to parents is needed to increase knowledge and reduce parental anxiety about the pandemic conditions. The resulting outputs are (1) Compilation of videos and booklets as information media, (2) education for parents carried out well online, (3) providing assistance to parents and teachers affected by the COVID-19 pandemic, distributed according to those requiring (4) publications. Based on this, it is hoped that the implementation of children's educational activities at home can run well, children can apply health protocols as expected.
\end{abstract}

Keywords: COVID-19 Pandemic; Education; Education; Anxiety 


\section{PENDAHULUAN}

Virus Corona diambil dari bahasa latin yang berarti mahkota, sebab bentuk virus corona memiliki paku yang menonjol menyerupai mahkota dan korona matahari. Virus Corona adalah keluarga besar virus yang dapat menginfeksi burung dan mamalia, termasuk manusia. Menurut World Health Organization (WHO) virus ini menyebabkan penyakit mulai dari flu ringan hingga infeksi pernapasan yang lebih parah seperti MERSCoV DAN SARS-CoV.

Pada tanggal 13 Maret 2020 di Indonesia terdapat 69 orang yang terjangkit virus corona, dua di antaranya adalah anak-anak. Masing-masing anak berusia 2 tahun dengan kondisi fisik sedang dan anak berusia 3 tahun dengan kondisi fisik ringan-sedang. Sampai saat ini di wilayah Kabupaten Purworejo khususnya daerah Kecamatan Purworejo merupakan yang paling tinggi kasus COVID-19. Wilayah KB/RA Alfa Kids berada di wilayah Kecamatan Purworejo dengan jumlah siswa total kurang lebih 50 mahasiswa.

Berkembangnya virus corona saat ini tidak hanya berdampak di bidang kesehatan namun juga pada sektor lainnya termasuk pendidikan. Pemerintah mengeluarkan peraturan bahwa proses pendidikan dan pembelajaran dilakukan dirumah dengan pendampingan langsung oleh orang tua (Ainun, 2020).

Peraturan yang dikeluarkan oleh pemerintah terkait pendampingan pembelajaran yang dilakukan dirumah menuntut orang tua terlebih seorang ibu untuk memaksimalkan perannya dalam menerapkan berbagai jenis dan model pola asuh yang paling tepat untuk mendampingi anak-anaknya di rumah terkhusus jika mereka masih berusia pra-sekolah karena pada usia ini anak masih aktif dan energik, ingin menang sendiri, sedikit susah diatur bahkan seringkali tidak mendengarkan orang lain (Ainun, 2020).

Akibat dari COVID-19 ini juga dapat menyebabkan kecemasan pada berbagai pihak tidak terkecuali para orang tua. Dengan banyaknya pemberitaan mengenai COVID-19 di televisi bahkan media sosial membuat orang tua merasa cemas dan dapat menularkan kecemasan tersebut kepada anak-anak (Antara, 2020).

Menurut Psikolog Universitas Indonesia (UI) Dr. Rose Mini, karantina mandiri yang dilakukan dirumah memiliki dampak pada psikologis anak. Kecemasan pada anak dapat timbul akibat larangan keluar rumah dan juga dapat ditimbulkan dari informasi yang diberikan orangtua bahwa orang yang terpapar COVID-19 ini pasti meninggal (Firdausya, 2020). 
Kecemasan tersebut juga akan berdampak pada proses pembelajaran yang didampingi orang tua, karena diberbagai lapisan masyarakat banyak ditemukan pola asuh yang dilakukan orang tua pada anak-anaknya masih dengan cara yang keras, membentak, memaksa dan bahkan sampai memukul jika anaknya tidak mau menuruti kemauan orang tuanya dalam hal belajar hingga anaknya menangis (Firdausya, 2020).

Pola asuh yang kurang tepat banyak dilakukan orang tua dalam kondisi saat ini. Rasa cemas dan panik menjadi alasan utamnya dan mengharapkan agar anak menjadi pandai dengan tekanan-tekanan yang diberikan. Hal tersebut dapat menimbulkan dampak negatif yang dirasakan oleh anak. Pola asuh tersebut termasuk cara-cara otoriter yakni pola asuh orang tua yang lebih mengutamakan membentuk kepribadian anak dengan cara menetapkan standar mutlak harus dipatuhi (Situmorang, 2020).

Anak-anak dikhawatirkan lebih rentan terkena virus COVID-19 karena virus ini seringkali dihubungkan sebagai penyakit dengan system imun rendah. Di Indonesia sendiri sudah ada anak-anak yang positif terinfeksi virus COVID-19. Anak-anak yang divonis positif COVID-19 mengalami gejala yang lebih ringan dibanding orang dewasa. Karena cara penularan virus corona pada anak-anak sama dengan orang dewasa, maka tindakan prefentif yang harus dilakukan juga sama.

Dampak dari COVID-19 ini dirasakan oleh semua pihak tidak terkecuali para orang tua wali siswa di Kelompok Bermain/RA Alfa Kids. Banyak orang tua yang merasa cemas dan panik dengan adanya COVID-19 ini. Menurut Komisioner Bidang Pendidikan Komisi Perlindungan Anak Indonesia (KPAI) Retno Listyarti dalam Liputan 6 (2020), jika para orang tua merasa cemas maka akan berdampak pada anak-anaknya. Selain itu orang tua perlu diberikan edukasi terkait perannya dalam upaya mencegah penularan virus COVID19. Dapat secara ekonomi juga dirasakan oleh guru dan orang tua dimana beberapa perkerjaan orang tua menjadi tidak dapat dilaksanakan dan tidak mendapat masukan pendapatan sehingga merasa kesulitan dan membiayai sekolah anak yang tetap harus dibayarkan meskipun pandemi seperti ini.

\section{METODE PELAKSANAAN}

Metode pelaksanaan untuk menyelesaikan permasalahan tersebut adalah dengan pemberian edukasi terkait COVID-19 dan upaya pencegahannya pada anak prasekolah serta pemberian bantuan bagi wali murid dan guru yang terdampak. Kegiatan ini dilaksanakan pada bulan Mei-Juni 2020 di KB/RA Alfa Kids Purworejo dengan sasaran adalah para wali/orang tua murid KB/RA Alfa Kids Purworejo. Jumlah sasaran untuk 
edukasi adalah 43 wali murid dan bakti sosial pemberian bantuan sejumlah 20 paket. Luaran dari kegiatan ini adalah pemberian edukasi, bakti sosial sampai dengan publikasi hasil pengabdian masyarakat.

\section{HASIL, PEMBAHASAN, DAN DAMPAK}

Kegiatan yang dilakukan dalam pengabdian masyarakat ini adalah :

1. Penyusunan video dan booklet sebagai media edukasi tentang upaya pencegahan COVID-19 pada anak-anak

2. Pemberian edukasi pada orang tua wali siswa KB/RA Alfa Kids tentang upaya pencegahan COVID-19

Tabel 1. Kegiatan Pemberian Edukasi pada Orang Tua/Wali Siswa tentang Upaya Pencegahan COVID-19

\begin{tabular}{|c|c|c|}
\hline $\begin{array}{c}\text { Deskripsi dan Tujuan } \\
\text { Kegiatan }\end{array}$ & Sasaran & Evaluasi/Dampak \\
\hline 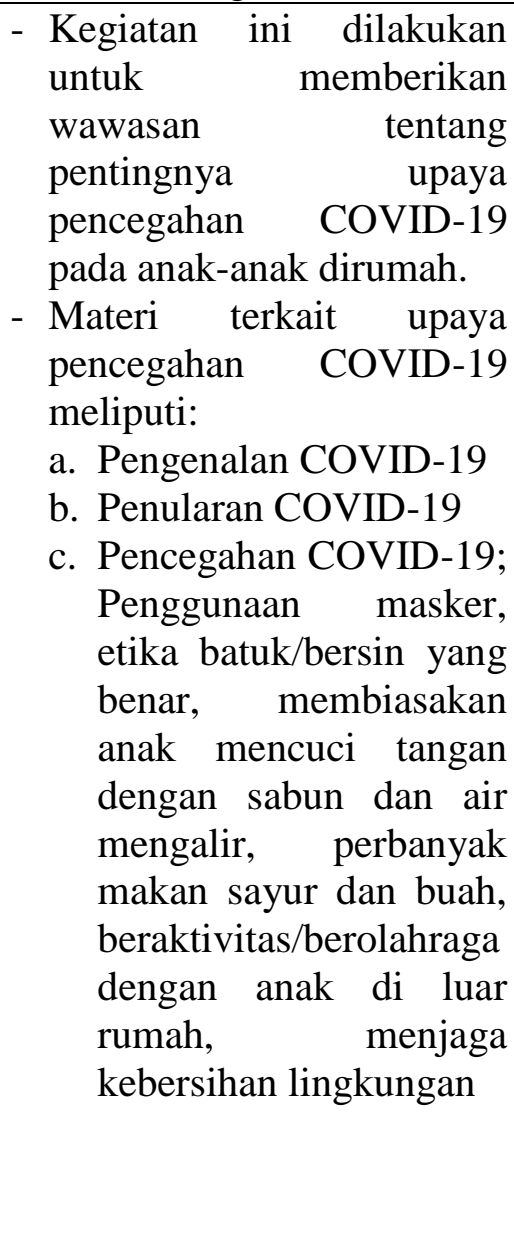 & $\begin{array}{lr}\text { Orang tua } & \text { siswa } \\
\text { KB/RA } & \text { Alfa } \\
\text { Kids } & \end{array}$ & $\begin{array}{l}\text { Sebelum kegiatan pengabdian } \\
\text { masyarakat : } \\
\text { - Orang tua/wali murid merasa } \\
\text { ketakutan dengan penularan } \\
\text { COVID-19 } \\
\text { - Anak-anak dirasa tidak aman } \\
\text { bahkan ketika berinteraksi dengan } \\
\text { anggota keluar lain yang harus } \\
\text { beraktivitas di luar rumah } \\
\text { Setelah kegiatan pengabdian } \\
\text { masyarakat: } \\
\text { - Video yang dibuat dan booklet } \\
\text { dapat dipahami dengan baik oleh } \\
\text { orang tua wali siswa sehingga } \\
\text { dapat menerapkan } \\
\text { mencontohkan pada anak-anak } \\
\text { dengan bahasa/media yang bisa } \\
\text { dipahami anak-anak } \\
\text { - Anak-anak dapat mengerti dan } \\
\text { dengan bantuan orang tua bisa } \\
\text { menerapkan protokol kesehatan } \\
\text { pencegahan COVID-19 } \\
\text { - Berkurangangnya rasa cemas } \\
\text { orang tua dengan penerapan } \\
\text { protokol kesehatan pencegahan } \\
\text { COVID-19 yang tepat pada anak }\end{array}$ \\
\hline
\end{tabular}

3. Bakti sosial pemberian bantuan sembako untuk wali murid dan guru yang terdampak COVID-19 
Tabel 2. Kegiatan Bakti Sosial Pemberian Sembako

\begin{tabular}{|c|c|c|}
\hline $\begin{array}{c}\text { Deskripsi dan Tujuan } \\
\text { Kegiatan }\end{array}$ & Sasaran & Evaluasi/Dampak \\
\hline 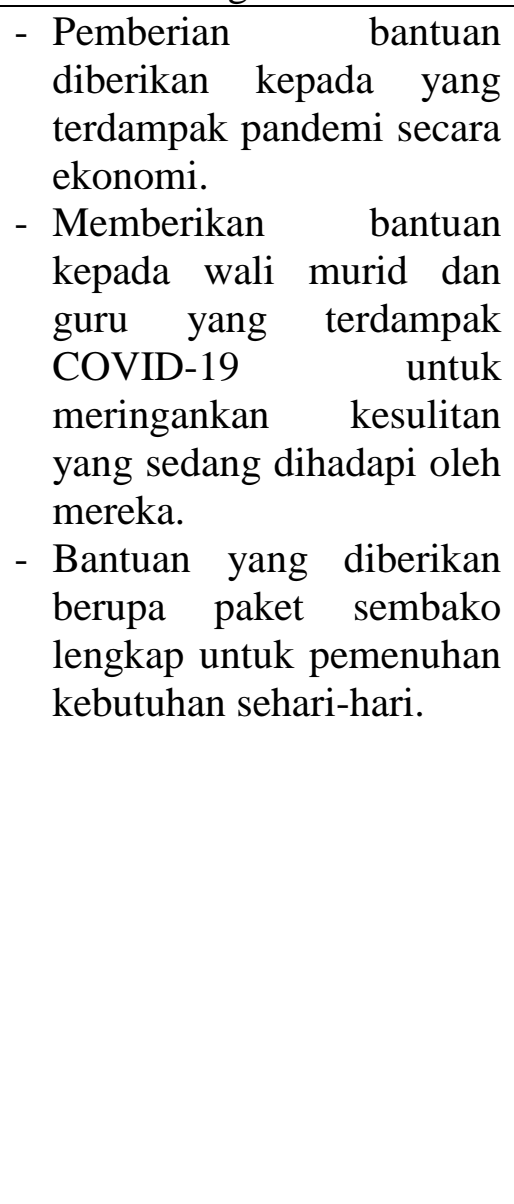 & $\begin{array}{l}\text { Orang } \\
\text { siswa, tua/wali } \\
\text { karyawan dan warga } \\
\text { di sekitar KB/RA } \\
\text { Alfa Kids }\end{array}$ & $\begin{array}{lr}\text { Sebelum kegiatan bakti sosial: } \\
\text { - } \text { Beberapa orang tua/wali } \\
\text { murid, guru, karyawan, dan } \\
\text { warga sekitar merasa } \\
\text { bahwa dengan pandemi ini } \\
\text { membatasi gerak untuk } \\
\text { bekerja seperti sebelum } \\
\text { pandemi } \\
\text { berdampak sehingga } \\
\text { kemampuan ekonomi } \\
\text { keluarga dan pemenuhan } \\
\text { kebutuhan sehari-hari. } \\
\text { Setelah kegiatan bakti sosial: } \\
\text { - Bantuan berupa sembako } \\
\text { diserahkan kepada sekolah } \\
\text { untuk pendistribusiannya } \\
\text { kepada wali murid, guru, } \\
\text { karyawan dan warga } \\
\text { disekitar KB/RA Alfa Kids } \\
\text { yang benar-benar } \\
\text { membutuhkan. } \\
\text { Sasaran yang mendapatkan } \\
\text { sembako merasa sangat } \\
\text { terbantu dan sedikit ringan } \\
\text { bebannya }\end{array}$ \\
\hline
\end{tabular}

Virus Corona diambil dari bahasa latin yang berarti mahkota, sebab bentuk virus corona memiliki paku yang menonjol menyerupai mahkota dan korona matahari. Virus Corona adalah keluarga besar virus yang dapat menginfeksi burung dan mamalia, termasuk manusia. Menurut World Health Organization (WHO) virus ini menyebabkan penyakit mulai dari flu ringan hingga infeksi pernapasan yang lebih parah seperti MERS-

\section{CoV DAN SARS-CoV.}

Virus Corona bersifat zoonosis, artinya virus ini menurupakan penyakit yang dapat ditularkan antara hewan dan manusia, contohnya rabies dan malaria. Begitu pula dengan MERS yang ditularkan dari unta ke manusia. Corona ini bertanggung jawab atas beberapa wabah diseluruh dunia, termasuk pandemic Severe Acute Respiratory Syndrome (SARS) 2002-2003 dan wabah Middle East Respiratory Syndrome (MERS) di Korea Selatan pada tahun 2015. Baru baru ini Virus Corona baru muncul dan dikenal sebagai COVID-19 yang muncul pertama kali di Cina pada bulan Desember 2019, dan merebak berbagai Negara sehingga WHO mendeklarasikannya sebagai pademi global, termasuk Indonesia yang 
sudah terpapar oleh virus corona mulai sejak tanggal 14 Febuari 2020 hingga sekarang, dan seluruh warga Indonesia diminta untuk mengurangi aktivitas atau kegiatan diluar rumah (Stay Safe) agar mencegah terjadinya penuluran virus corona semakin banyak.

Himbauan terkait social distancing yang dianjurkan oleh pemerintah juga menuntut orang tua untuk mengerjakan pekerjaan kantor dirumah. Hal ini menjadi beban orang tua untuk mengerjakan semua pekerjaan dirumah dalam satu waktu, terlebih jika mereka mempunyai anak lebih dari 1 yang usianya masih tergolong kecil, seperti bayi. Oleh karena itu, orang tua harus bisa membagi waktu untuk setiap pekerjaan termasuk menjadi pendamping ketika anak melakukan proses pembelajaran dirumah. Orang tua juga harus pandai menggali karakter anak sehingga proses pembelajaran yang dilakukan dirumah dapat berjalan lancar (Ainun, 2020).

Menurut Dr. Noer Rohmah perlakuan orang tua dalam layanan bimbingan pada anak di rumah setidaknya harus menampilkan hal-hal seperti, menerima anak apa adanya, memperlakukan anak dengan penuh kasih sayang, tidak menuntut anak untuk menunjukkan perubahan perilaku dengan segera, tidak memaksa anak untuk memenuhi keinginan orang tua, sabar, penuh kehangatan dan toleransi pemaaf, menghargai dan memberi kebebasan pada anak (Ainun, 2020).

WHO memberikan tips untuk membatu orang tua menerapkan pola asuh yang benar kepada anak dalam kondisi COVID-19 ini serta membatu orang tua untuk berinteraksi secara konstruktif dengan anak-anak mereka selama masa karantina atau social distancing ini. Tips yang diberikan yaitu menghabiskan waktu bersama anak, tetap berpikir positif, buat struktur atau rencana yang akan dilakukan, mengatasi perilaku yang kurang baik, tetap tenang dan kelola stress, mendiskusikan COVID-19 (WHO, 2020).

Cuci tangan merupakan suatu prosedur atau tindakan membersihkan tangan menggunakan sabun dan air mengalir atau hand sanitizer (berbasis alkohol). Teknik mencuci tangan menggunakan sabun dan air mengalir yaitu membuka kran dan membasahi tangan, menuangkan sabun cair ket telapak tangan, melakukan gerakan tangan mulai dari meratakan sabun dengan kedua telapak tangan, kedua punggung telapak tangan saling menumpuk secara bergantian, bersihkan telapak tangan dan sela-sela jari secara menyilang, membersihkan buku-buku jari secara bergantian, membersihkan ibu jari secara bergantian, posisikan jari-jari tangan mengerucut dan putar kedalamberalaskan telapak tangan secara bergantian, bilas tangan menggunakan air mengalir. Mencuci tangan merupakan teknik dasar yang paling penting dalam mencegah dan pengontrolan infeksi termasuk pencegahan virus COVID-19. Dengan melakukan cuci tangan yang benar akan 
menjaga kebersihan tangan dan mencegah dari terpapar bakteri dan virus termasuk virus COVID-19.

\section{SIMPULAN}

Kegiatan pengabdian masyarakat dalam upaya pencegahan COVID-19 untuk anak pra sekolah sangat diperlukan untuk memberikan edukasi pada orang tua bagaimana memahamkan pada anak tentang COVID-19 dan protokol kesehatan yang mudah dipahami dan mudah diterapkan oleh anak-anak. Pemberian edukasi ini berdampak baik dengan pemahaman anak-anak dalam upaya untuk pencegahan COVID-19 pada dirinya dengan informasi dari orang tua. Pemberian batuan kepada wali murid dan guru KB/RA Alfa Kids terdistribusi tepat kepada yang membutuhkan sehingga dapat sedikit meringankan beban warga yang terdampak pandemi.

\section{UCAPAN TERIMA KASIH}

Terima kasih kami ucapkan kepada Rektor Universitas 'Aisyiyah Yogyakarta, Ketua LPPM Universitas 'Aisyiyah, kepala, guru dan orang tua siswa KB/RA Alfa Kids dan semua pihak yang telah membantu kelancaran kegiatan ini.

\section{DAFTAR PUSTAKA}

Ainun, Y. (2020, Maret 27). Kopi Times. Retrieved Maret 31, 2020, from Times Indonesia: https://www.timesindonesia.co.id/read/news/259829

Antara. (2020, Maret 20). Gaya. Retrieved Maret 31, 2020, from Tempo.co: https://gaya.tempo.co/read/1322010

Daryanto. (2016). Media Pembelajaran. Yogyakarta: Gava Meidika.

Firdausya, I. (2020, Maret 19). Humaniora. Retrieved Maret 31, 2020, from Media Indonesia: https://mediaindonesia.com/read/detail/297659

Kemenkes RI. (2020). Situasi Terkini Perkembangan Coronavirus Disease (COVID-19) 31 Maret 2020. Jakarta: Kemenkes RI.

Liputan 6. (2020). Studi Ungkap Orangtua dan Anak Sering Konflik Selama Pandemi Corona COVID-19. Jakarta: Liputan 6.

Nugroho, R. S. (2020, Maret 7). Tren. Retrieved April 2, 2020, from Kompas.com: https://www.kompas.com/tren/read/2020/03/07/150000165 
Owen, L. (2020, Maret 9). News. Retrieved Maret 31, 2020, from BBC: https://www.bbc.com/indonesia/indonesia-51717312

Pemprov Jateng. (2020). Kasus COVID-19 Bertambah, Ganjar Ambil Langkah Preventif, Kuratif dan Promotif. Semarang: Pemerintah Provinsi Jawa Tengah.

Samodro, D. (2020, Maret 19). Berita. Retrieved April 1, 2020, from Antara Sumbar: https://sumbar.antaranews.com/berita/337266

Situmorang, C. H. (2020, Maret 18). Redaksi. Retrieved April 1, 2020, from Kronologi id: https://kronologi.id/2020/03/18/himbauan-presiden-efektifkah

Suwarta, T. H. (2020, Maret 18). Humaniora. Retrieved April 1, 2020, from Media Indonesia: https://mediaindonesia.com/read/detail/297518

WHO. (2020). Coronavirus Disease (COVID-2019) Situation Reports. Jenewa: WHO.

WHO. (2020, Maret). www.who.int. Retrieved Maret 31, 2020, from QA for public: https://www.who.int/indonesia/news/novel-coronavirus/qa-for-public 